\title{
NEW MODEL FOR COLOUR KINETICS OF PLUM UNDER INFRARED VACUUM CONDITION AND MICROWAVE DRYING
}

\author{
Reza Amiri Chayjan $\bowtie$, Behnam Alaei \\ Department of Biosystems Engineering, Faculty of Agriculture, Bu-Ali Sina University \\ Postal Code: 6517833131, Hamedan, Iran
}

\begin{abstract}
Background. Quality of dried foods is affected by the drying method and physiochemical changes in tissue. The drying method affects properties such as colour. The colour of processed food is one of the most important quality indices and plays a determinant role in consumer acceptability of food materials and the processing method. The colour of food materials can be used as an indirect factor to determine changes in quality, since it is simpler and faster than chemical methods.

Material and methods. The study focused on the kinetics of colour changes of plum slices, under infrared vacuum and microwave conditions. Drying the samples was implemented at the absolute pressures of 20 and $60 \mathrm{kPa}$, drying temperatures of 50 and $60^{\circ} \mathrm{C}$ and microwave power of $90,270,450$ and $630 \mathrm{~W}$. Colour changes were quantified by the tri-stimulus $L^{*}$ (whiteness/darkness), $a^{*}$ (redness/greenness) and $b^{*}$ (yellowness/blueness) model, which is an international standard for color measurement developed by the Commission Internationale d'Eclairage (CIE). These values were also used to calculate total colour change $(\Delta E)$, chroma, hue angle, and browning index $(B I)$. A new model was used for mathematical modelling of colour change kinetics.

Results. The drying process changed the colour parameters of $L^{*}, a^{*}$, and $b^{*}$, causing a colour shift toward the darker region. The values of $L^{*}$ and hue angle decreased, whereas the values of $a^{*}, b^{*}, \Delta E$, chroma and browning index increased during exposure to infrared vacuum conditions and microwave drying. Comparing the results obtained using the new model with two conventional models of zero-order and first-order kinetics indicated that the new model presented more compatibility with the data of colour kinetics for all colour parameters and drying conditions.

Conclusion. All kinetic changes in colour parameters can be explained by the new model presented in this study. The hybrid drying system included infrared vacuum conditions and microwave power for initial slow drying of plum slices and provided the desired results for colour change.
\end{abstract}

Key words: plum slices, colour change, kinetics model of colour changes, infrared vacuum dryer, microwave dryer

\section{INTRODUCTION}

The plum is native to Europe, United States and China. The major producers are including USA, France, Italy, Argentina, Chile and Turkey (Sabarez and Price, 1999), with Iran's plum production in 2011 standing at 285,205 t (FAO, 2012). Plums are low in fat and calories and high in carbohydrates. They are an excellent source of potassium, iron calcium, magnesium, vitamin $\mathrm{A}$, vitamin $\mathrm{C}$ and fibre. Plums are often dried 
because of the short harvest season and are also used for jams or thick syrups. In addition, plum juice is widely used as a cool drink and flavouring in the food industry (Sabarez et al., 1997).

The plum has a short shelf life and is prone to microbial spoilage. Therefore, drying and preservation is necessary for commercial additives as well as for household consumption. Drying is one of the oldest and most important thermal processing techniques aimed at inactivating enzymes, reducing water activity and restraining deteriorative microbial growth (Krokida et al., 2001). However, common drying techniques such as convective drying impart inappropriate effects on the quality of foods mainly because of the physicochemical changes in tissue during drying. Hence a kinetic model of the thermal process is necessary to design and optimize new approaches to obtain a food product with high quality (Dadal1 et al., 2007a; Dadalı et al., 2007b).

Colour parameters of $L^{*}$ (whiteness/darkness), $a^{*}$ (redness/greenness) and $b^{*}$ (yellowness/blueness) can be utilized to describe colour degradation and provide useful data for quality control in vegetables and fruits (Maskan et al., 2002). Other parameters such as total colour change, chroma and hue angle have been derived from the $L^{*}, a^{*}$, and $b^{*}$ scale. Total colour change $(\Delta E)$ indicates the mean colour change of the processed sample related to the initial conditions. Chroma indicates colour saturation and is proportional to its intensity. Hue angle is often used to specify colour in agricultural and food products. Angles of $0^{\circ}$ or $360^{\circ}$ represent a red hue, while angles of $90^{\circ}, 180^{\circ}$, and $270^{\circ}$ indicate yellow, green, and blue hues, respectively. Hue angle is useful in the evaluation of colour parameters, especially in meats, fruits and green vegetables. Browning index $(B I)$ is the purity of brown colour and is an important parameter in drying processes with respect to enzymatic and non-enzymatic browning reactions (Maskan, 2001).

The study of colour change behaviour in agricultural and food products during drying has been a subject of interest for various researchers, such as a mix of spinach and mustard leaves (Ahmed et al., 2002), sesame seeds (Kahyaoglu and Kaya, 2006) and sucuk (Bozkurt and Bayram, 2006). While there are many studies on kinetic changes in fruits and vegetables in the literature, no study has been reported on the kinetics of colour change while drying plums in infrared vacuum conditions and microwave drying. Furthermore, modelling of colour change kinetics has been limited to zero-order and first-order kinetic models. Therefore, the purpose of this study was to propose a new model to estimate the colour change kinetics of plum slices under infrared vacuum conditions and microwave drying.

\section{MATERIAL AND METHODS}

Fresh plum samples of the Avalon plum variety were purchased from a market in Hamedan, Iran. The skin and flesh colour of these Avalon plum varieties were red and deep red-purple and golden yellow, respectively. After thorough cleaning, washing and peeling the plums were cut into $1.5 \mathrm{~mm}$ thickness. Ambient air temperature and air relative humidity during drying changed from 25 to $32^{\circ} \mathrm{C}$ and 22 to $36 \%$, respectively. The initial moisture content of the plum slices was determined using the gravimetric method at $70^{\circ} \mathrm{C}$ for $24 \mathrm{~h}$ (AOAC, 2002). The initial moisture content of the plum samples was $5.52 \%$ (d.b.), while the final moisture content after the drying process was about $0.09 \%$ (d.b.).

The infrared-vacuum dryer included a drying chamber as a hollow cylinder with inner dimensions of $12 \times 32 \mathrm{~cm}$. In order to perform thermal insulation, the cylinder is made of Teflon. An infrared lamp (100 W) with quartz elements was used to heat the drying chamber. It was installed at the top of the drying chamber. The distance between the end of the lamp and the sample tray was about $8 \mathrm{~cm}$. The air temperatures in the dryer chamber and near the tray sample were recorded using a thermometer with a type $\mathrm{k}$ sensor and an accuracy of $\pm 0.1^{\circ} \mathrm{C}$ (Lutron TM-903, Taiwan). The vacuum conditions in the drying chamber were created by a vacuum pump (DV-285N-250- PLATINUM, USA). A pressure controller with an accuracy of 0.001 bar was used to determine and maintain absolute pressure during the tests (Sensys PSCH0001 BCIJ, Korea). The temperature of the drying chamber was controlled by a thermostat (Atbin 400k, Iran).

A microwave oven (Sharp, R959SLMA, Thailand) with a maximum power of $900 \mathrm{~W}$ was used as a microwave dryer. This device was applied to dry samples while the air temperature and microwave power were 
controlled. The air temperature during the tests was set at $40^{\circ} \mathrm{C}$. Microwave power and operation time can be adjusted in the domestic oven.

The sample weight during the experiments was recorded using a digital balance (AND GF-6000, Japan) with $\pm 0.01 \mathrm{~g}$ accuracy. Air relative humidity was measured by a hygrometer with an accuracy of $\pm 3 \%$ RH (Lutron TM-903, Taiwan). A flatbed colour scanner (HP, Scanjet G4050, USA) with a maximum 1200 DPI was used in this study.

During drying, the plum slices were removed from the dryers at time intervals for colour measurement. Most commercial instruments for colour measurement do not have adequate accuracy for food engineering studies, because they are designed and calibrated basically for quality control. This paper provides a simple approach that uses a flatbed scanner for colour measuring and Photoshop graphic software for analyzing colour. By means of "measure", the colour values of the pixels on the food surface were obtained by the flatbed scanner. The illuminant of the scanner was determined using the standard colorimetric card. All pixels of the sample surface were selected and those colour values manipulated to obtain colour distribution, averages, and so on were performed in accordance with the term 'analyze'.

$L^{*} a^{*} b^{*}$ values are device-independent and cover a greater extent than RGB and CMYK. For quantitative analysis, the $L^{*} a^{*} b^{*}$ method was used in this study. Photoshop software can compute and represent $L a b$ values (also RGB and CMYK values) in the Info Palette and Histogram Window. But the values of $L$, $a$, and $b$ displayed in the Histogram window are not standard colour values. Therefore they are converted to standard values of $L^{*} a^{*} b^{*}$ using the following formulae (Yam and Papadakis, 2004):

$$
\begin{gathered}
L^{*}=\frac{\text { Lightness }}{255} \times 100 \\
a^{*}=\frac{240 a}{255}-120 \\
b^{*}=\frac{240 b}{255}-120
\end{gathered}
$$

The total colour change, chroma, hue angle and browning index were calculated from the $L^{*} a^{*} b^{*}$ values and used to describe the colour change during drying:

$$
\Delta E=\sqrt{\left(L_{0}^{*}-L_{t}^{*}\right)^{2}+\left(a_{0}^{*}-a_{t}^{*}\right)^{2}+\left(b_{0}^{*}-b_{t}^{*}\right)^{2}}
$$

$L_{0}{ }^{*}, a_{0}{ }^{*}, b_{0}{ }^{*}$ are the initial colour measurements of the plum slices and $L_{t}^{*}, a_{t}^{*}, b_{t}^{*}$ are the colour measurements at pre-specified times:

$$
\begin{gathered}
\text { Chroma }=\left(a_{t}^{* 2}+b_{t}^{* 2}\right)^{0.5} \\
\text { Hue angle }=\tan ^{-1}\left(\frac{b_{t}^{*}}{a_{t}^{*}}\right) \\
B I=\frac{[100(x-0.31)]}{0.17} \\
x=\frac{\left(a_{t}^{*}+1.75 L_{t}^{*}\right)}{\left(5.645 L_{t}^{*}+a^{*}-3.012 b_{t}^{*}\right)}
\end{gathered}
$$

where: $\Delta E$ - the total colour change, $B I$ - the browning index, $L_{0}^{*}, a_{0}^{*}, b_{0}^{*}$ - the initial colour measurements of the plum slices, $L_{t}^{*}, a_{t}^{*}, b_{t}^{*}$ - the colour measurements at pre-specified times.

To investigate the effect of infrared vacuum conditions on colour change kinetics of plum slices, seven slices of plum fruit with a weight of about $40 \mathrm{~g}$ were dried in an infrared vacuum dryer with the absolute pressures of 20 and $60 \mathrm{kPa}$ and drying temperatures (the temperature of the dryer chamber) of 50 and $60^{\circ} \mathrm{C}$. Moreover, about $40 \mathrm{~g}$ of plum slices were dried in a microwave dryer with a power of $90,270,450$ and $630 \mathrm{~W}$. The $L, a$ and $b$ of the samples were recorded during drying at pre-specified time intervals.

In order to determine the colour change of food and agricultural materials as a function of drying time, several models for the application of colour change kinetics have been reported (Avila and Silva, 1999; Chen and Ramaswamy, 2002; Maskan, 2001). Generally, the change rate of a quality factor $C$ can be represented by the following model:

$$
\frac{d C}{d t}=-k C^{n}
$$

where: $k$ - the kinetic rate constant, $C$ - the concentration of a quality factor $C$ at time $t, n$ - the order of reaction. For the majority of foods, the time-dependence relationships appear to be described by zero-order models (Garza et al., 1999; Maskan, 2001) or first-order kinetic models (Chen and Ramaswamy, 2002; Krokida et al., 2001; Maskan et al., 2002). 
By integrating Eq. (8), zero-order (Eq. 9) and firstorder kinetic models (Eq. 10) can be derived as:

$$
\begin{gathered}
C=C_{0} \pm k t \\
C=C_{0} \times \exp ( \pm k t)
\end{gathered}
$$

where: $C$ - the colour value at a pre-specified time, $C_{0}$ - the initial value of the colour. Symptom \pm indicates the formation and degradation of any quality parameter (Prachayawarakorn et al., 2004).

The following model is presented as a new model in this study in order to determine the colour change of food materials as a function of drying time:

$$
C=C_{0} \cdot \exp \left( \pm k t^{n}\right)+a \cdot t^{n}
$$

where: $C_{0}$ - the initial value of colour, $C$ - the colour value at a pre-specified time. In the equations, \pm indicates the formation and degradation of any quality parameter. Parameter $a$ is the equation constant. The kinetic rate can be calculated as Eq. (12):

$$
K R=C_{0} \cdot\left(k \cdot n \cdot t^{n-1}\right) \cdot e^{k \cdot t^{n}}+a \cdot n \cdot t^{n-1}
$$

where: $K R$ - the kinetic rate constant, $C_{0}-$ the initial value of colour and $n, k$ and $a$ are the constants of Eq. (11).

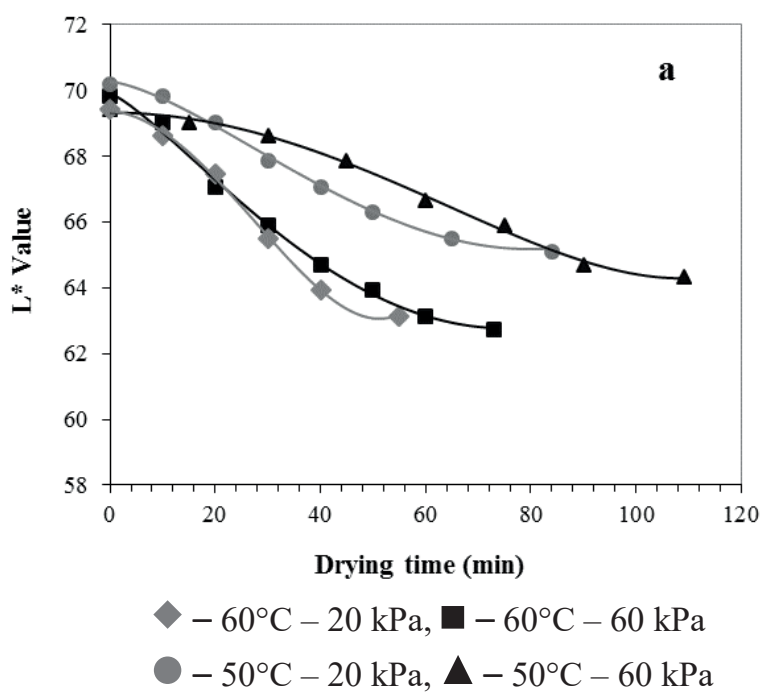

The order reaction of colour parameters in infrared vacuum conditions and during microwave drying of plum slices was determined by the adjustment of the experimental data to the integrated Eqs. (9), (10) and (11) using regression analysis. In each case, the best fit was selected and the kinetic rate constant at each process was determined.

Regression analysis was performed using MATLAB R2012a software. Reduced chi-square $\left(\chi^{2}\right)$, root mean square error (RMSE) and the coefficient of determination $\left(R^{2}\right)$ were used as the primary criteria to select the best fit of the mathematical model being tested to the experimental data. The superiority of the models was evaluated with a higher value of $R^{2}$ and lower values of $\chi^{2}$ and $R M S E$.

\section{RESULTS AND DISCUSSION}

The values of $L^{*}, a^{*}, b^{*}$ and total colour change $(\Delta E)$ obtained from the experimental data during different drying conditions are presented in Figures 1 to 4, respectively. Figure 1a shows the maximum (65.75) and minimum (62.75) value of $L^{*}$ at the end of infrared vacuum processing achieved at $50^{\circ} \mathrm{C}-20 \mathrm{kPa}$ and $60^{\circ} \mathrm{C}-60 \mathrm{kPa}$, respectively. The initial $L^{*}$ value of

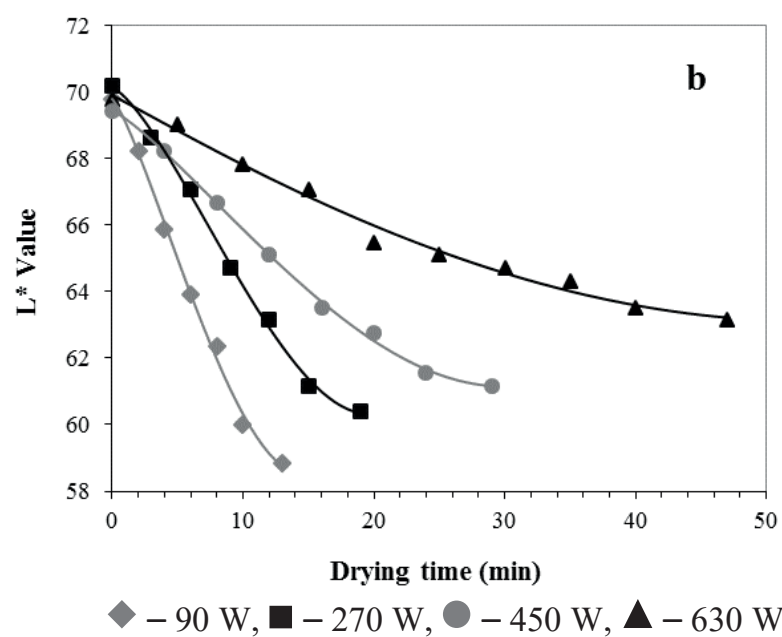

Fig. 1. Kinetics change of the $L^{*}$ value colour parameter under different drying conditions: a - infrared vacuum condition, $\mathrm{b}$ - microwave drying 
Chayjan, R. A., Alaei, B. (2016). New model for colour kinetics of plum under infrared vacuum condition and microwave drying. Acta Sci. Pol. Technol. Aliment., 15(2), 131-144. DOI: 10.17306/J.AFS.2016.2.13
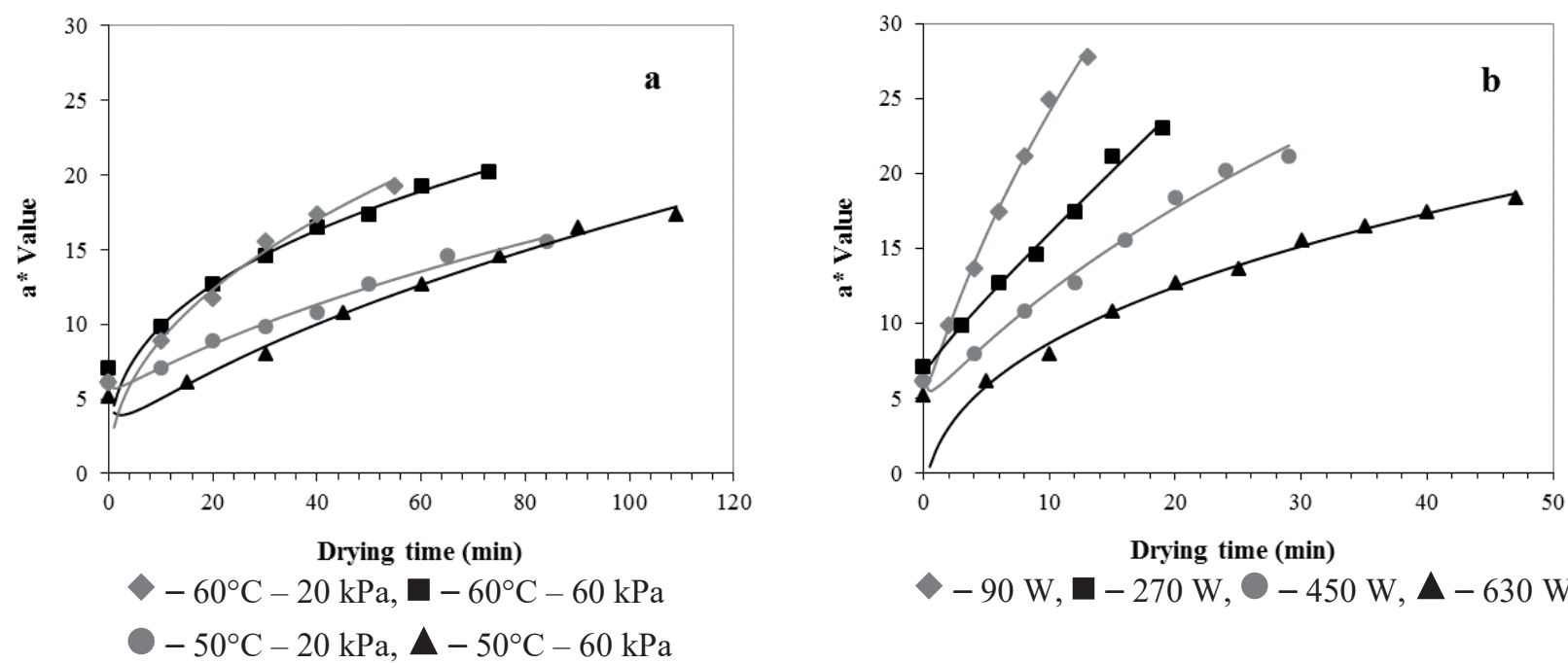

Fig. 2. Kinetics change of the $a^{*}$ value colour parameter under different drying conditions: a - infrared vacuum condition, $\mathrm{b}$ - microwave drying
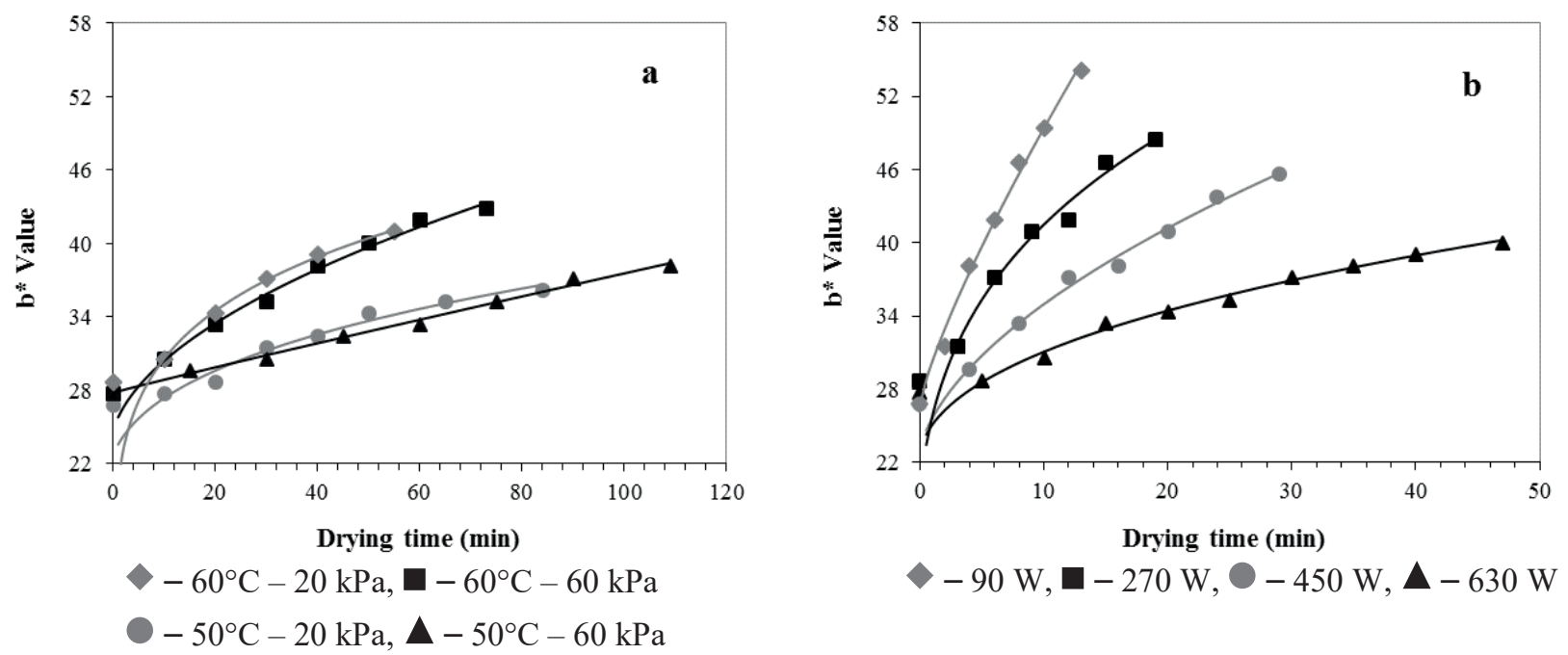

Fig. 3. Kinetics change of the $b^{*}$ value colour parameter under different drying conditions: a - infrared vacuum condition, $\mathrm{b}$ - microwave drying

the samples was 70.20 . Furthermore, Figure $1 \mathrm{~b}$ shows the maximum (63.14) and minimum (58.82) value of $L^{*}$ at the end of microwave processing achieved at $90 \mathrm{~W}$ and $630 \mathrm{~W}$, respectively. It can be observed that changes in the brightness of dried samples can be taken as an indicator of browning during the drying of plum slices (Dadalı et al., 2007a; Dadalı et al., 2007b).

For the redness/greenness scale $\left(a^{*}\right)$, the initial colour value of plum samples was between 5.18 and 7.06 and the final values after drying in infrared vacuum conditions increased to between 15.53 and 20.24, while by means of microwave power this increased to between 18.35 and 27.76 (Fig. 2). Therefore all plum slices became redder with increased drying time.

For the yellownessblueness scale $\left(b^{*}\right)$, the initial colour value of plum samples was between 26.82 and 28.71 and the final values increased after drying in infrared vacuum conditions to between 36.24 and 42.82 , 

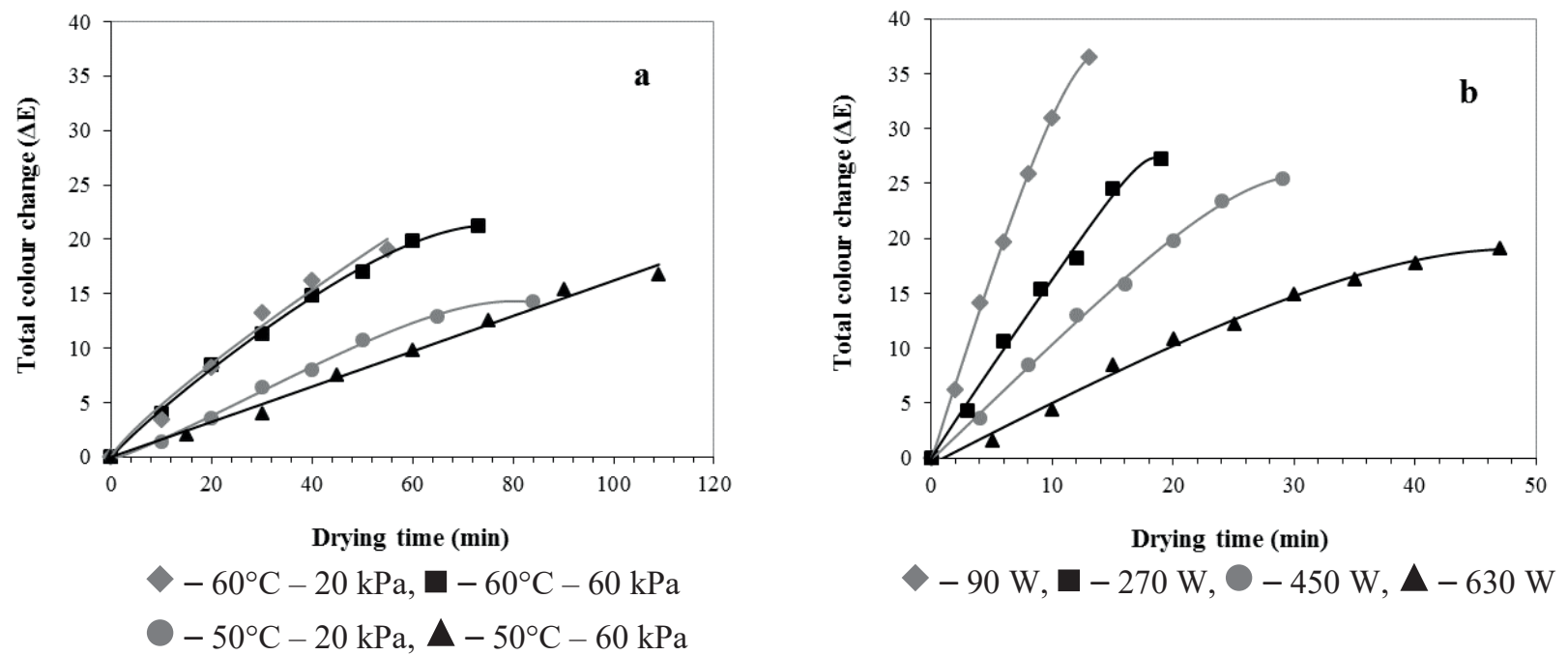

Fig. 4. Kinetics change of the total colour change $(\Delta E)$ under different drying conditions: a - infrared vacuum condition, $\mathrm{b}$ - microwave drying

and by means of microwave drying increased to between 40 and 54.12 (Fig. 3). Variations in the $b^{*}$ value at a higher air temperature, absolute pressure and microwave power were increased. Under higher levels of input variables, the chemical reaction rate was increased. These results are similar to previous studies, such as one on garlic slices (Prachayawarakorn et al., 2004).

As a whole, the total colour change $(\Delta E)$ of plum slices increased significantly during the drying process with drying time. For infrared vacuum conditions, $\Delta E$ values ranged from 14.25 to 21.22 and at various microwave output powers ranged from 19.18 to 36.53 (Fig. 4). Therefore it can be concluded that some modifications would have occurred in the optical properties of plum slices (changes due to oxidation processes or other chemical reactions) during the drying process with a decrease in moisture content and an increase in air temperature, absolute pressure and microwave power levels, which may not be acceptable to the consumer. When food preparations are heatprocessed, a number of chemical reactions occur. One of them is the well-known Millard reaction (Milton, 1985), known to be responsible for non-enzymatic browning. The Maillard reaction involves the reaction of an aldehyde (usually a reducing sugar) and an amine (usually a protein or amino acid) and is highly temperature-dependent.
For mathematical modelling of colour changes in plum slices, zero-order, first-order and new kinetic models were used. The estimated kinetic parameters of these models, corresponding values of coefficients of determination $\left(R^{2}\right)$, reduced chi-square $\left(\chi^{2}\right)$ and root mean square error (RMSE) are presented in Table 1 . The modelling results of the plum colour change showed that $L^{*}$ values for all drying conditions except for $50^{\circ} \mathrm{C}-60 \mathrm{kPa}$ under infrared vacuum drying could be adequately characterised by the first-order model, whereas the kinetics of $a^{*}, b^{*}$ and $\Delta E$ could be described by the zero-order model under all drying conditions. The kinetics of $L^{*}, a^{*}, b^{*}$ and $\Delta E$ under infrared vacuum conditions and various microwave powers could be described by the new model with more values of $R^{2}$ and fewer values of $\chi^{2}$ and RMSE compared to the zero-order and first-order models. Values of kinetics change of the $L^{*}, a^{*}, b^{*}$ and $\Delta E$ as a function of drying time with an interval of 60 seconds were predicted for infrared vacuum conditions and 30 seconds for microwave drying by the new model in Figures 1-4, respectively.

The kinetic rate constant based on zero-order and first-order models under infrared vacuum conditions and microwave drying decreased for $L^{*}$ and increased for $a^{*}, b^{*}$ and $\Delta E$ with increasing air temperature and microwave power levels and decreasing absolute pressure. This implies that the degradation rate of colour 
Chayjan, R. A., Alaei, B. (2016). New model for colour kinetics of plum under infrared vacuum condition and microwave drying. Acta Sci. Pol. Technol. Aliment., 15(2), 131-144. DOI: 10.17306/J.AFS.2016.2.13

Table 1. The statistical values of zero-order, first-order and new models for $L^{*}, a^{*}, b^{*}$ and $\Delta E$ for various drying conditions

\begin{tabular}{|c|c|c|c|c|c|c|c|c|c|c|}
\hline \multirow{2}{*}{$\begin{array}{l}\text { Param- } \\
\text { eters }\end{array}$} & \multirow{2}{*}{ Drying condition } & \multicolumn{3}{|c|}{ Zero-order model } & \multicolumn{3}{|c|}{ First-order model } & \multicolumn{3}{|c|}{ New model* } \\
\hline & & $R^{2}$ & $\chi^{2}$ & $R M S E$ & $R^{2}$ & $\chi^{2}$ & $R M S E$ & $R^{2}$ & $\chi^{2}$ & $R M S E$ \\
\hline \multirow[t]{8}{*}{$L^{*}$} & $50^{\circ} \mathrm{C}-20 \mathrm{kPa}$ & 0.9585 & 1.096 & 0.4274 & 0.9624 & 0.9946 & 0.4071 & 0.9983 & 0.0458 & 0.1070 \\
\hline & $50^{\circ} \mathrm{C}-60 \mathrm{kPa}$ & 0.9761 & 0.646 & 0.3282 & 0.9744 & 0.6918 & 0.3396 & 0.9973 & 0.0722 & 0.1344 \\
\hline & $60^{\circ} \mathrm{C}-20 \mathrm{kPa}$ & 0.9696 & 0.995 & 0.4988 & 0.9710 & 0.9503 & 0.4874 & 0.9990 & 0.0333 & 0.1290 \\
\hline & $60^{\circ} \mathrm{C}-60 \mathrm{kPa}$ & 0.9585 & 2.034 & 0.5823 & 0.9643 & 1.753 & 0.5406 & 0.9966 & 0.1686 & 0.2053 \\
\hline & $90 \mathrm{~W}$ & 0.9561 & 2.104 & 0.5128 & 0.9613 & 1.856 & 0.4816 & 0.9903 & 0.4672 & 0.2791 \\
\hline & $270 \mathrm{~W}$ & 0.9731 & 1.775 & 0.5438 & 0.9783 & 1.432 & 0.4886 & 0.9986 & 0.0925 & 0.1521 \\
\hline & $450 \mathrm{~W}$ & 0.9830 & 1.424 & 0.5336 & 0.9864 & 1.142 & 0.4778 & 0.9979 & 0.1798 & 0.2448 \\
\hline & $630 \mathrm{~W}$ & 0.9852 & 1.488 & 0.5455 & 0.9892 & 1.083 & 0.4653 & 0.9971 & 0.2933 & 0.3127 \\
\hline \multirow[t]{8}{*}{$a^{*}$} & $50^{\circ} \mathrm{C}-20 \mathrm{kPa}$ & 0.9822 & 1.425 & 0.4890 & 0.9432 & 4.575 & 0.8732 & 0.9900 & 0.8047 & 0.4485 \\
\hline & $50^{\circ} \mathrm{C}-60 \mathrm{kPa}$ & 0.9841 & 2.421 & 0.6352 & 0.9374 & 9.525 & 1.2600 & 0.9947 & 0.7990 & 0.4469 \\
\hline & $60^{\circ} \mathrm{C}-20 \mathrm{kPa}$ & 0.9692 & 4.024 & 1.0030 & 0.9046 & 12.46 & 1.7650 & 0.9917 & 1.0860 & 0.7369 \\
\hline & $60^{\circ} \mathrm{C}-60 \mathrm{kPa}$ & 0.9631 & 5.450 & 0.9531 & 0.9056 & 13.95 & 1.5250 & 0.9982 & 0.2612 & 0.2555 \\
\hline & $90 \mathrm{~W}$ & 0.9683 & 6.405 & 0.8948 & 0.9007 & 20.06 & 1.5840 & 0.9951 & 0.9851 & 0.4046 \\
\hline & $270 \mathrm{~W}$ & 0.9853 & 3.247 & 0.7357 & 0.9357 & 14.24 & 1.5410 & 0.9925 & 1.6670 & 0.6456 \\
\hline & $450 \mathrm{~W}$ & 0.9919 & 1.652 & 0.5747 & 0.9602 & 8.101 & 1.2730 & 0.9922 & 1.5950 & 0.7292 \\
\hline & $630 \mathrm{~W}$ & 0.9898 & 3.844 & 0.8768 & 0.9274 & 27.31 & 2.3370 & 0.9968 & 1.2180 & 0.6373 \\
\hline \multirow[t]{8}{*}{$b^{*}$} & $50^{\circ} \mathrm{C}-20 \mathrm{kPa}$ & 0.9494 & 4.524 & 0.8683 & 0.9314 & 6.135 & 1.0110 & 0.9811 & 1.6890 & 0.6498 \\
\hline & $50^{\circ} \mathrm{C}-60 \mathrm{kPa}$ & 0.9922 & 0.731 & 0.3490 & 0.9883 & 1.096 & 0.4225 & 0.9925 & 0.7059 & 0.4201 \\
\hline & $60^{\circ} \mathrm{C}-20 \mathrm{kPa}$ & 0.9677 & 3.739 & 0.9668 & 0.9489 & 5.925 & 1.2170 & 0.9991 & 0.1046 & 0.2287 \\
\hline & $60^{\circ} \mathrm{C}-60 \mathrm{kPa}$ & 0.9775 & 4.618 & 0.8773 & 0.9568 & 8.876 & 1.2160 & 0.9951 & 1.0090 & 0.5023 \\
\hline & $90 \mathrm{~W}$ & 0.9724 & 4.622 & 0.7601 & 0.9553 & 7.489 & 0.9675 & 0.9949 & 0.8512 & 0.3767 \\
\hline & $270 \mathrm{~W}$ & 0.9828 & 5.296 & 0.9395 & 0.9626 & 11.52 & 1.3860 & 0.9948 & 1.5860 & 0.6296 \\
\hline & $450 \mathrm{~W}$ & 0.9691 & 9.999 & 1.4140 & 0.9450 & 17.81 & 1.8870 & 0.9901 & 3.2060 & 1.0340 \\
\hline & $630 \mathrm{~W}$ & 0.9818 & 10.46 & 1.4460 & 0.9488 & 29.40 & 2.4250 & 0.9939 & 3.5210 & 1.0830 \\
\hline \multirow[t]{8}{*}{$\Delta E$} & $50^{\circ} \mathrm{C}-20 \mathrm{kPa}$ & 0.9715 & 5.536 & 0.9605 & 0.8391 & 31.25 & 2.2820 & 0.9971 & 0.5685 & 0.3770 \\
\hline & $50^{\circ} \mathrm{C}-60 \mathrm{kPa}$ & 0.9912 & 2.376 & 0.7707 & 0.8984 & 27.30 & 2.1330 & 0.9914 & 2.3150 & 0.6212 \\
\hline & $60^{\circ} \mathrm{C}-20 \mathrm{kPa}$ & 0.9718 & 7.817 & 1.3980 & 0.8414 & 44.01 & 3.3170 & 0.9813 & 5.1960 & 1.6120 \\
\hline & $60^{\circ} \mathrm{C}-60 \mathrm{kPa}$ & 0.9722 & 11.120 & 1.3610 & 0.8533 & 58.76 & 3.1290 & 0.9989 & 0.4513 & 0.3359 \\
\hline & $90 \mathrm{~W}$ & 0.9706 & 12.210 & 1.2360 & 0.8477 & 63.32 & 2.8130 & 0.9940 & 2.4790 & 0.6428 \\
\hline & $270 \mathrm{~W}$ & 0.9870 & 7.691 & 1.1320 & 0.8799 & 71.09 & 3.4420 & 0.9981 & 1.0960 & 0.5234 \\
\hline & $450 \mathrm{~W}$ & 0.9847 & 9.249 & 1.3600 & 0.8782 & 73.82 & 3.8420 & 0.9943 & 3.4430 & 1.0710 \\
\hline & $630 \mathrm{~W}$ & 0.9870 & 13.580 & 1.6480 & 0.8736 & 132.4 & 5.1450 & 0.9992 & 0.8269 & 0.5250 \\
\hline
\end{tabular}

* The new model was the best. 
was faster as a result of higher energy transfer to the food material, causing an increase in the temperature of the product. The results were in agreement with those reported in the literature, such as, concentrated tomato paste (Barreiro et al., 1997), pear puree (Ibarz et al., 1999), peach puree (Avila and Silva, 1999; Garza et al., 1999), kiwifruits (Maskan, 2001), okra (Dadalı et al., 2007a) and spinach (Dadalı et al., 2007b).

The kinetic rate constants on the same slope of the diagram showing colour change parameters and absolute diameter of the kinetic rate had an inverse relationship with drying time. Using zero-order and first-order models it is possible to obtain the kinetic rate constant, while by the new model can show the kinetic rate at any time with Eq. (12). The estimated kinetic parameters of zero-order, first-order and new kinetic model for $L^{*}, a^{*}, b^{*}$, and $\Delta E$ under different drying conditions are presented in Tables 3-5, respectively.

The results of these experiments indicated that the kinetics of colour change of plum slices under infrared vacuum conditions were more non-linear and complex compared to microwave drying, since there are two parameters of air temperature and absolute pressure influencing the drying. In contrast, in microwave drying, only the factor of microwave power was the effective parameter (Fig. 1-7).

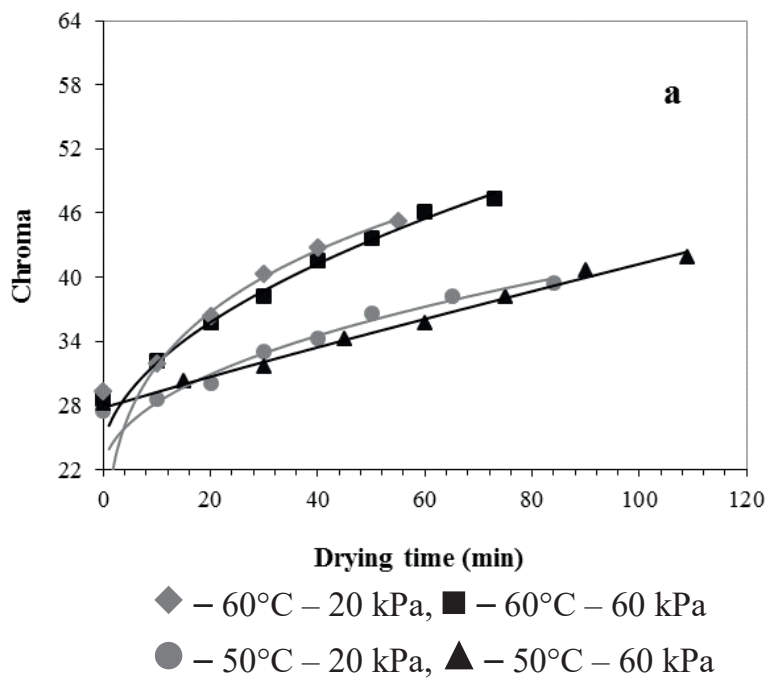

Chroma, hue angle, and browning index were calculated using Eqs. (5-7) and the results illustrated in Figures 5-7, respectively. The maximum increase in chroma value ranged from 27.51 to 47.36 with a drying time at $60^{\circ} \mathrm{C}-60 \mathrm{kPa}$ under infrared vacuum conditions, also during microwave drying with the applied microwave output power. The maximum increase in the chroma value under microwave conditions increased from 27.49 to 60.82 at a microwave power of $60 \mathrm{~W}$, and closely followed the $b^{*}$ values (Fig. 5). The final chroma values of the samples by infrared vacuum conditions were lower than the values of microwave output powers. These results indicated that inconstancy of the yellow colour in plum slices under the conditions applied is similar those in a tunnel dryer (Goyal et al., 2007).

The maximum decrease in hue angle occurred during the infrared vacuum condition process, from 79.44 to 64.71 at $60^{\circ} \mathrm{C}-60 \mathrm{kPa}$. The maximum decrease in the hue angle during microwave drying ranged from 79.23 to 62.84 with a microwave power of $90 \mathrm{~W}$. The results indicated that the colour of plum slices gained redness with an increase in drying time, air temperature, absolute pressure and microwave power level (Fig. 6).

The browning index $(B I)$ of the samples increased during the drying process. The maximum increase

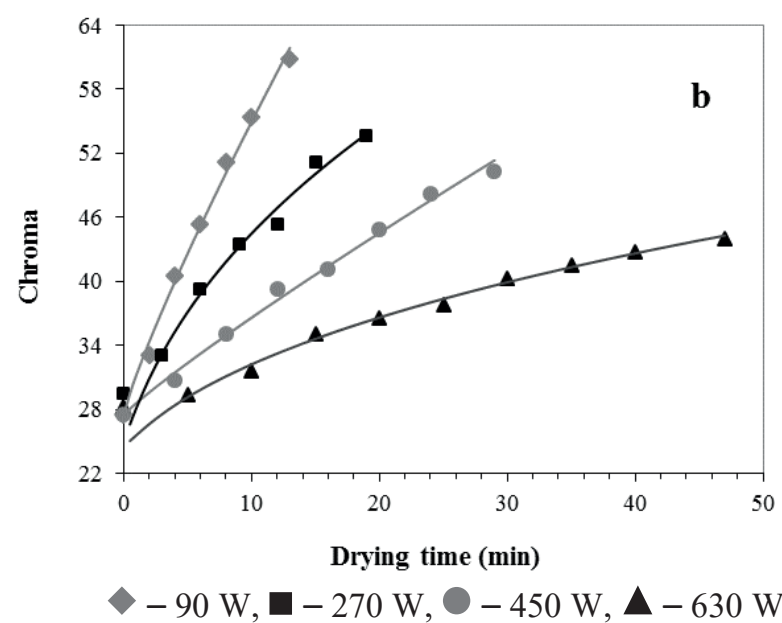

Fig. 5. Kinetics change of the chroma as a colour parameter under different drying conditions: a - infrared vacuum condition, $\mathrm{b}$ - microwave drying 
Chayjan, R. A., Alaei, B. (2016). New model for colour kinetics of plum under infrared vacuum condition and microwave drying. Acta Sci. Pol. Technol. Aliment., 15(2), 131-144. DOI: 10.17306/J.AFS.2016.2.13
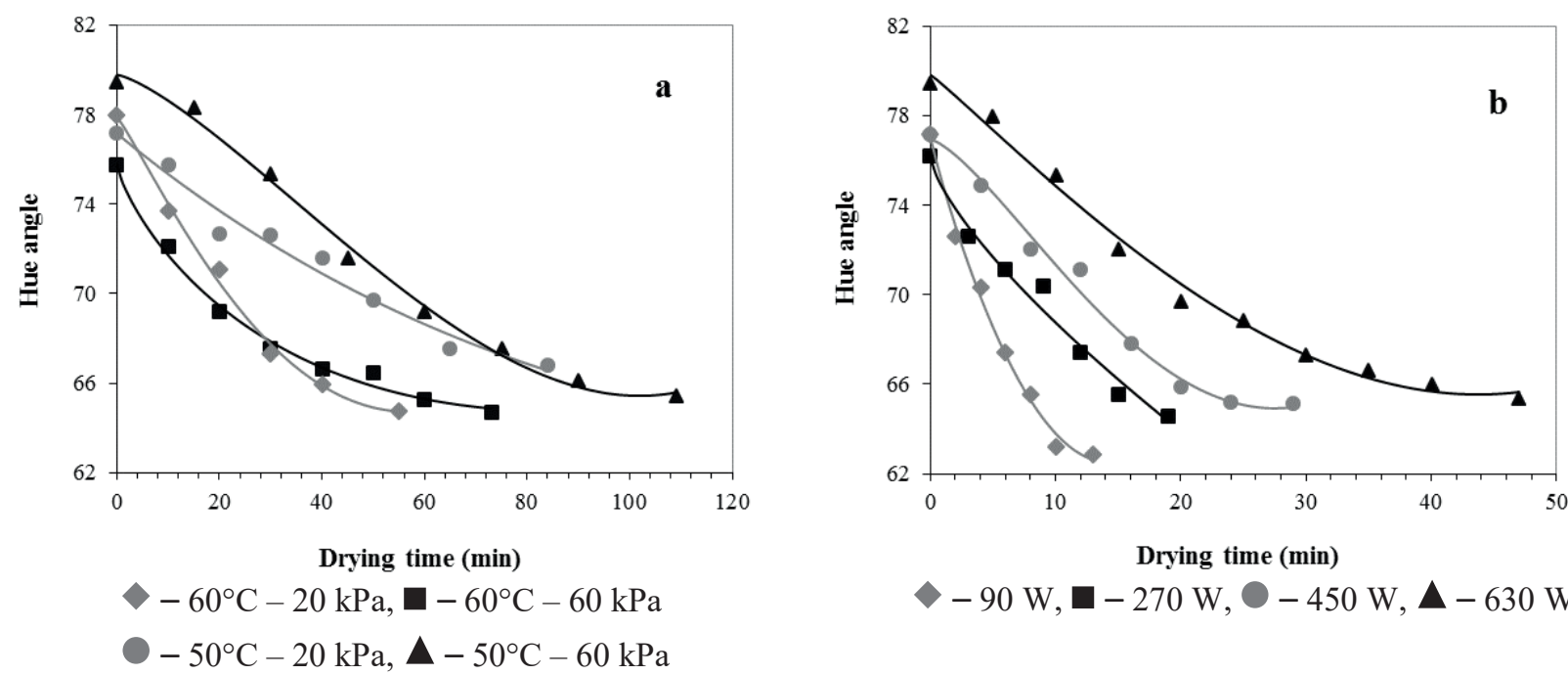

Fig. 6. Kinetics change of the Hue angle as a colour parameter under different drying conditions: a - infrared vacuum condition, $\mathrm{b}$ - microwave drying
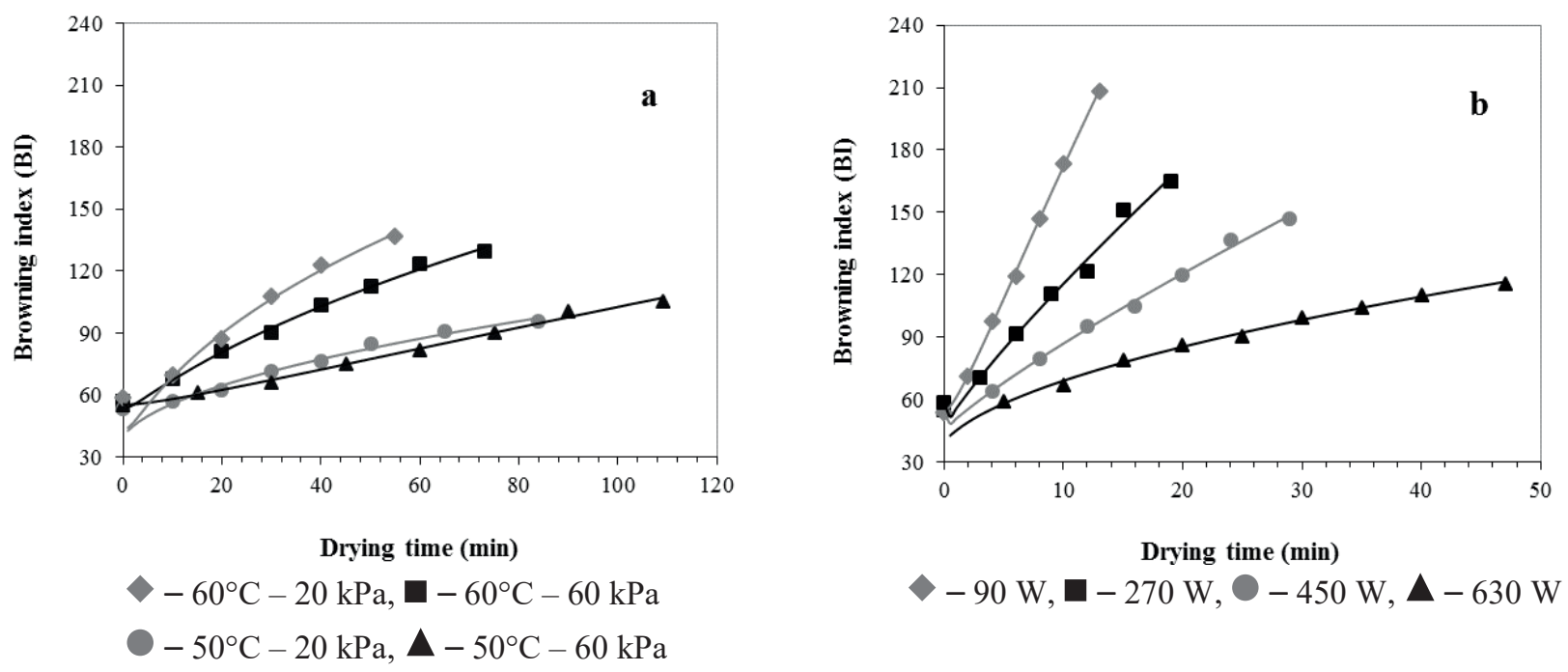

Fig. 7. Kinetics change of the Browning index $(B I)$ as a colour parameter under different drying conditions: a - infrared vacuum condition, $\mathrm{b}$ - microwave drying

under infrared vacuum conditions occurred from 53.54 to 136.79 at $60^{\circ} \mathrm{C}-20 \mathrm{kPa}$. The maximum increase in $B I$ under microwave power ranged from 53.68 to 208.28 at $90 \mathrm{~W}$. The browning index $-B I$ represents the purity of the brown colour and is reported as an important parameter in processes where enzymatic and non-enzymatic browning takes place (Palou et al., 1999). The significant increment in the $B I$ values may be due to the well-known Maillard reaction (non-enzymatic browning) between naturally occurring reducing sugars and compounds containing an amino group, e.g. amino acids, peptides and proteins, which results in the formation of coloured melanoidins. Furthermore, the rate at which the Maillard reaction proceeds to form the coloured pigments increases markedly with drying conditions. These results suggest that infrared vacuum conditions for drying plum slices are better than microwave drying. 
Chayjan, R. A., Alaei, B. (2016). New model for colour kinetics of plum under infrared vacuum condition and microwave drying. Acta Sci. Pol. Technol. Aliment., 15(2), 131-144. DOI: 10.17306/J.AFS.2016.2.13

Table 2. The statistical values of zero-order, first-order and new models for chroma, hue angle and browning index (BI) for various drying conditions

\begin{tabular}{|c|c|c|c|c|c|c|c|c|c|c|}
\hline \multirow{2}{*}{$\begin{array}{l}\text { Param- } \\
\text { eters }\end{array}$} & \multirow{2}{*}{ Drying condition } & \multicolumn{3}{|c|}{ Zero-order model } & \multicolumn{3}{|c|}{ First-order model } & \multicolumn{3}{|c|}{ New model* } \\
\hline & & $R^{2}$ & $\chi^{2}$ & $R M S E$ & $R^{2}$ & $\chi^{2}$ & $R M S E$ & $R^{2}$ & $\chi^{2}$ & $R M S E$ \\
\hline \multirow[t]{8}{*}{ Chroma } & $50^{\circ} \mathrm{C}-20 \mathrm{kPa}$ & 0.9657 & 4.762 & 0.8909 & 0.9471 & 7.341 & 1.106 & 0.9874 & 1.752 & 0.6619 \\
\hline & $50^{\circ} \mathrm{C}-60 \mathrm{kPa}$ & 0.9931 & 1.177 & 0.4430 & 0.9881 & 2.022 & 0.5805 & 0.9932 & 1.158 & 0.5379 \\
\hline & $60^{\circ} \mathrm{C}-20 \mathrm{kPa}$ & 0.9722 & 5.420 & 1.1640 & 0.9502 & 9.707 & 1.558 & 0.9981 & 0.3738 & 0.4323 \\
\hline & $60^{\circ} \mathrm{C}-60 \mathrm{kPa}$ & 0.9778 & 6.961 & 1.0770 & 0.9534 & 14.61 & 1.561 & 0.9965 & 1.084 & 0.5206 \\
\hline & $90 \mathrm{~W}$ & 0.9759 & 6.770 & 0.9199 & 0.9559 & 12.42 & 1.246 & 0.9957 & 1.203 & 0.4478 \\
\hline & $270 \mathrm{~W}$ & 0.9881 & 5.513 & 0.9585 & 0.9663 & 15.66 & 1.615 & 0.9928 & 3.334 & 0.913 \\
\hline & $450 \mathrm{~W}$ & 0.9804 & 9.324 & 1.3660 & 0.9573 & 20.35 & 2.017 & 0.9919 & 3.853 & 1.133 \\
\hline & $630 \mathrm{~W}$ & 0.9872 & 11.09 & 1.4900 & 0.9525 & 41.08 & 2.866 & 0.9949 & 4.393 & 1.210 \\
\hline \multirow{8}{*}{$\begin{array}{l}\text { Hue } \\
\text { angle }\end{array}$} & $50^{\circ} \mathrm{C}-20 \mathrm{kPa}$ & 0.9580 & 3.911 & 0.8074 & 0.9636 & 3.391 & 0.7518 & 0.9767 & 2.168 & 0.7363 \\
\hline & $50^{\circ} \mathrm{C}-60 \mathrm{kPa}$ & 0.9541 & 9.698 & 1.2710 & 0.9633 & 7.745 & 1.136 & 0.9950 & 1.066 & 0.5162 \\
\hline & $60^{\circ} \mathrm{C}-20 \mathrm{kPa}$ & 0.9271 & 9.405 & 1.5330 & 0.9412 & 7.592 & 1.378 & 0.9948 & 0.6649 & 0.5766 \\
\hline & $60^{\circ} \mathrm{C}-60 \mathrm{kPa}$ & 0.8588 & 13.99 & 1.5270 & 0.8725 & 12.63 & 1.451 & 0.9927 & 0.7219 & 0.4248 \\
\hline & $90 \mathrm{~W}$ & 0.9222 & 18.34 & 1.5140 & 0.9367 & 14.93 & 1.366 & 0.9918 & 1.928 & 0.5669 \\
\hline & $270 \mathrm{~W}$ & 0.9424 & 8.607 & 1.1980 & 0.9522 & 7.146 & 1.091 & 0.9888 & 1.668 & 0.6458 \\
\hline & $450 \mathrm{~W}$ & 0.9656 & 3.500 & 0.8367 & 0.9702 & 3.029 & 0.7784 & 0.9807 & 1.966 & 0.8096 \\
\hline & $630 \mathrm{~W}$ & 0.9330 & 11.04 & 1.4860 & 0.9474 & 8.658 & 1.316 & 0.9948 & 0.8632 & 0.5364 \\
\hline \multirow[t]{8}{*}{$B I$} & $50^{\circ} \mathrm{C}-20 \mathrm{kPa}$ & 0.9734 & 46.05 & 2.7700 & 0.9461 & 93.49 & 3.947 & 0.9892 & 18.74 & 2.164 \\
\hline & $50^{\circ} \mathrm{C}-60 \mathrm{kPa}$ & 0.9913 & 20.44 & 1.8460 & 0.9867 & 31.16 & 2.279 & 0.9940 & 14.16 & 1.882 \\
\hline & $60^{\circ} \mathrm{C}-20 \mathrm{kPa}$ & 0.9848 & 71.10 & 4.2160 & 0.9523 & 223.5 & 7.476 & 0.9908 & 17.26 & 2.938 \\
\hline & $60^{\circ} \mathrm{C}-60 \mathrm{kPa}$ & 0.9885 & 54.79 & 3.0220 & 0.9562 & 209 & 5.902 & 0.9966 & 16.26 & 2.016 \\
\hline & $90 \mathrm{~W}$ & 0.9852 & 60.95 & 2.7600 & 0.9553 & 183.9 & 4.794 & 0.9973 & 11.08 & 1.359 \\
\hline & $270 \mathrm{~W}$ & 0.9957 & 33.78 & 2.3730 & 0.9725 & 214.6 & 5.98 & 0.9970 & 23.05 & 2.401 \\
\hline & $450 \mathrm{~W}$ & 0.9891 & 101.9 & 4.5140 & 0.9681 & 298.9 & 7.731 & 0.9911 & 83.39 & 5.272 \\
\hline & $630 \mathrm{~W}$ & 0.9977 & 43.06 & 2.9350 & 0.9738 & 484 & 9.839 & 0.9994 & 10.6 & 1.880 \\
\hline
\end{tabular}

* The new model was the best.

The modelling studies showed that the values calculated for chroma and browning index could be adequately described using a zero-order model compared to a first-order model. On the other hand, the data for hue angle followed the first-order kinetic model for all drying conditions of plum slices. But the new model predicted the kinetics of chroma, hue angle and browning index with a higher value for the corresponding coefficients of determination $\left(R^{2}\right)$ and lower values for reduced chi-square $\left(\chi^{2}\right)$ and root mean square error (RMSE) for all drying conditions (Table 2). Predictions for the kinetics of the chroma, 
Chayjan, R. A., Alaei, B. (2016). New model for colour kinetics of plum under infrared vacuum condition and microwave drying. Acta Sci. Pol. Technol. Aliment., 15(2), 131-144. DOI: 10.17306/J.AFS.2016.2.13

Table 3. The estimated kinetic parameters values of the zero-order model for various drying conditions

\begin{tabular}{|c|c|c|c|c|c|c|c|c|c|}
\hline \multirow{2}{*}{$\begin{array}{l}\text { Param- } \\
\text { eters }\end{array}$} & \multirow{2}{*}{$\begin{array}{l}\text { Coeffi- } \\
\text { cients }\end{array}$} & \multicolumn{4}{|c|}{ Infrared vacuum conditions } & \multicolumn{4}{|c|}{ Microwave drying } \\
\hline & & $\begin{array}{c}50^{\circ} \mathrm{C} \\
-20 \mathrm{kPa}\end{array}$ & $\begin{array}{c}50^{\circ} \mathrm{C} \\
-60 \mathrm{kPa}\end{array}$ & $\begin{array}{c}60^{\circ} \mathrm{C} \\
-20 \mathrm{kPa}\end{array}$ & $\begin{array}{c}60^{\circ} \mathrm{C} \\
-60 \mathrm{kPa}\end{array}$ & $90 \mathrm{~W}$ & $270 \mathrm{~W}$ & $450 \mathrm{~W}$ & $630 \mathrm{~W}$ \\
\hline \multirow[t]{2}{*}{$L^{*}$} & $K$ & -0.06723 & -0.0517 & -0.1253 & -0.1032 & -0.1458 & -0.3028 & -0.5516 & -0.8908 \\
\hline & $C_{0}$ & 70.11 & 69.8 & 69.58 & 69.43 & 69.31 & 69.08 & 70.09 & 69.62 \\
\hline \multirow[t]{2}{*}{$a^{*}$} & $K$ & 0.1188 & 0.1231 & 0.2503 & 0.1795 & 0.3011 & 0.558 & 0.8633 & 1.727 \\
\hline & $C_{0}$ & 6.267 & 4.889 & 6.71 & 8.356 & 5.588 & 6.236 & 7.234 & 6.669 \\
\hline \multirow[t]{2}{*}{$b^{*}$} & $K$ & 0.123 & 0.09706 & 0.2355 & 0.2132 & 0.2747 & 0.657 & 1.076 & 2.124 \\
\hline & $C_{0}$ & 27.05 & 27.91 & 29.05 & 28.69 & 28.21 & 27.66 & 29.49 & 28.16 \\
\hline \multirow[t]{2}{*}{$\Delta E$} & $K$ & 0.1835 & 0.1642 & 0.3653 & 0.2968 & 0.4326 & 0.913 & 1.484 & 2.878 \\
\hline & $C_{0}$ & 0.3067 & -0.1593 & 0.6103 & 1.609 & 0.7531 & 0.816 & 0.7508 & 1.4 \\
\hline \multirow[t]{2}{*}{ Chroma } & $K$ & 0.1546 & 0.1309 & 0.3064 & 0.2633 & 0.3569 & 0.8095 & 1.313 & 2.615 \\
\hline & $C_{0}$ & 27.69 & 28.17 & 29.73 & 29.86 & 28.64 & 28.22 & 30.22 & 28.76 \\
\hline \multirow{2}{*}{$\begin{array}{l}\text { Hue } \\
\text { angle }\end{array}$} & $K$ & -0.1262 & -0.1428 & -0.2433 & -0.1388 & -0.3175 & -0.4482 & -0.6023 & -1.109 \\
\hline & $C_{0}$ & 76.44 & 79.19 & 76.43 & 73.36 & 78.07 & 76.24 & 75.2 & 75.25 \\
\hline \multirow[t]{2}{*}{$B I$} & $K$ & 0.5488 & 0.4852 & 1.512 & 1.034 & 1.371 & 3.328 & 5.85 & 12.16 \\
\hline & $C_{0}$ & 53.51 & 53.73 & 58.02 & 59.05 & 55.54 & 53.26 & 56.42 & 49.71 \\
\hline
\end{tabular}

Table 4. The estimated kinetic parameters values of first-order model for various drying conditions

\begin{tabular}{|c|c|c|c|c|c|c|c|c|c|}
\hline \multirow{2}{*}{$\begin{array}{l}\text { Param- } \\
\text { eters }\end{array}$} & \multirow{2}{*}{$\begin{array}{l}\text { Coeffi- } \\
\text { cients }\end{array}$} & \multicolumn{4}{|c|}{ Infrared vacuum conditions } & \multicolumn{4}{|c|}{ Microwave drying } \\
\hline & & $\begin{array}{c}50^{\circ} \mathrm{C} \\
-20 \mathrm{kPa}\end{array}$ & $\begin{array}{c}50^{\circ} \mathrm{C} \\
-60 \mathrm{kPa}\end{array}$ & $\begin{array}{c}60^{\circ} \mathrm{C} \\
-20 \mathrm{kPa}\end{array}$ & $\begin{array}{c}60^{\circ} \mathrm{C} \\
-60 \mathrm{kPa}\end{array}$ & $90 \mathrm{~W}$ & $270 \mathrm{~W}$ & $450 \mathrm{~W}$ & $630 \mathrm{~W}$ \\
\hline \multirow[t]{2}{*}{$L^{*}$} & $K$ & 0.001003 & 0.0007703 & 0.001897 & 0.00158 & 0.002223 & 0.004703 & 0.00853 & 0.014 \\
\hline & $C_{0}$ & 70.15 & 69.83 & 69.63 & 69.52 & 69.38 & 69.19 & 70.22 & 69.78 \\
\hline \multirow[t]{2}{*}{$a^{*}$} & $K$ & -0.01017 & -0.0101 & -0.01718 & -0.01135 & -0.02217 & -0.03697 & -0.05419 & -0.0904 \\
\hline & $C_{0}$ & 7.07 & 6.306 & 8.078 & 9.527 & 7.162 & 7.929 & 8.737 & 9.284 \\
\hline \multirow[t]{2}{*}{$b^{*}$} & $K$ & -0.003754 & -0.002915 & -0.006503 & -0.005732 & -0.007804 & -0.01733 & -0.02646 & -0.04901 \\
\hline & $C_{0}$ & 27.37 & 28.18 & 29.5 & 29.32 & 28.67 & 28.55 & 30.47 & 29.87 \\
\hline \multirow[t]{2}{*}{$\Delta E$} & $K$ & -0.01981 & -0.01664 & -0.02934 & -0.02077 & -0.03432 & -0.05721 & -0.08811 & -0.1256 \\
\hline & $C_{0}$ & 3.062 & 3.08 & 4.201 & 5.28 & 4.389 & 5.444 & 5.668 & 7.87 \\
\hline \multirow[t]{2}{*}{ Chroma } & $K$ & -0.004445 & -0.003694 & -0.007853 & -0.00652 & -0.009468 & -0.01985 & -0.03007 & -0.05526 \\
\hline & $C_{0}$ & 28.15 & 28.63 & 30.42 & 30.75 & 29.35 & 29.46 & 31.53 & 31.1 \\
\hline \multirow{2}{*}{$\begin{array}{l}\text { Hue } \\
\text { angle }\end{array}$} & $K$ & 0.001782 & 0.002018 & 0.003541 & 0.002063 & 0.00456 & 0.006489 & 0.008706 & 0.01654 \\
\hline & $C_{0}$ & 76.58 & 79.5 & 76.7 & 73.55 & 78.42 & 76.47 & 75.35 & 75.57 \\
\hline \multirow[t]{2}{*}{$B I$} & $K$ & -0.006986 & -0.006035 & -0.01468 & -0.01035 & -0.0152 & -0.03207 & -0.05119 & -0.09222 \\
\hline & $C_{0}$ & 56.06 & 56.44 & 64.17 & 64.46 & 59.93 & 61.06 & 65.57 & 65.7 \\
\hline
\end{tabular}


Chayjan, R. A., Alaei, B. (2016). New model for colour kinetics of plum under infrared vacuum condition and microwave drying. Acta Sci. Pol. Technol. Aliment., 15(2), 131-144. DOI: 10.17306/J.AFS.2016.2.13

Table 5. The estimated kinetic parameter values of new model for various drying conditions

\begin{tabular}{|c|c|c|c|c|c|c|c|c|c|}
\hline \multirow[b]{2}{*}{$\begin{array}{l}\text { Param- } \\
\text { eters }\end{array}$} & \multirow{2}{*}{$\begin{array}{l}\text { Coeffi- } \\
\text { cients }\end{array}$} & \multicolumn{4}{|c|}{ Infrared vacuum conditions } & \multicolumn{4}{|c|}{ Microwave drying } \\
\hline & & $\begin{array}{l}50^{\circ} \mathrm{C}- \\
20 \mathrm{kPa}\end{array}$ & $\begin{array}{l}50^{\circ} \mathrm{C}- \\
60 \mathrm{kPa}\end{array}$ & $\begin{array}{l}60^{\circ} \mathrm{C}- \\
20 \mathrm{kPa}\end{array}$ & $\begin{array}{l}60^{\circ} \mathrm{C}- \\
60 \mathrm{kPa}\end{array}$ & $90 \mathrm{~W}$ & $270 \mathrm{~W}$ & $450 \mathrm{~W}$ & $630 \mathrm{~W}$ \\
\hline \multirow[t]{4}{*}{$L^{*}$} & $K$ & -0.00075 & 2.998 & 0.0003216 & -0.00237 & 0.006238 & 6.251 & 0.007111 & 0.01608 \\
\hline & $C_{0}$ & 70.26 & 69.32 & 69.36 & 69.9 & 69.9 & 64.43 & 70.12 & 69.79 \\
\hline & $a$ & 0.03396 & -0.002919 & -0.03251 & 0.09671 & -0.6417 & -0.6625 & -0.7845 & -1.818 \\
\hline & $\mathrm{n}$ & 1.455 & 1.992 & 1.794 & 1.256 & 1.04 & 1.242 & 1.396 & 1.269 \\
\hline \multirow[t]{4}{*}{$a^{*}$} & $K$ & -0.4425 & -0.5763 & -15.71 & 1.858 & 1.692 & -0.9081 & 0.7019 & -1.412 \\
\hline & $C_{0}$ & 6.122 & 5.183 & 6.12 & 7.06 & 5.181 & 6.126 & 7.068 & 6.126 \\
\hline & $a$ & 1.789 & 1.165 & 3.092 & 4.194 & -26.61 & 3.202 & -6.468 & 5.89 \\
\hline & $\mathrm{n}$ & 0.4904 & 0.5823 & 0.4624 & 0.3683 & 0.08892 & 0.5701 & 0.3035 & 0.6116 \\
\hline \multirow[t]{4}{*}{$b^{*}$} & $K$ & -0.959 & -2.341 & -23.94 & 0.592 & 0.7683 & 0.07289 & -2.291 & 2.518 \\
\hline & $C_{0}$ & 26.82 & 27.82 & 28.71 & 27.76 & 27.76 & 26.82 & 28.71 & 26.74 \\
\hline & $a$ & 13.32 & 0.1167 & 20.54 & -24.36 & -34.74 & -29.94 & 22.93 & 3.557 \\
\hline & $\mathrm{n}$ & 0.214 & 0.9612 & 0.1732 & 0.1667 & 0.1258 & 0.1745 & 0.2526 & 0.8039 \\
\hline \multirow[t]{4}{*}{$\Delta E$} & $K$ & 0.02251 & -2.34 & -3.306 & 0.08815 & 0.05999 & 0.1282 & 0.7346 & 0.2895 \\
\hline & $C_{0}$ & -0.2328 & 2.006 & 1.199 & -0.08996 & -0.5539 & -0.01291 & -9.057 & -0.2432 \\
\hline & $a$ & 0.1407 & 0.1599 & 0.6893 & 0.5727 & 0.6019 & 1.048 & 1.752 & 3.654 \\
\hline & $\mathrm{n}$ & 1.137 & 1.003 & 0.8409 & 0.897 & 1.001 & 1.015 & 0.969 & 0.9815 \\
\hline \multirow[t]{4}{*}{ Chroma } & $K$ & 0.6931 & 0.1831 & 1.478 & 0.6659 & -0.9037 & -0.00011 & -1.22 & -0.0003142 \\
\hline & $C_{0}$ & 27.51 & 28.26 & 29.35 & 28.65 & 28.24 & 27.46 & 29.56 & 27.41 \\
\hline & $a$ & -31.12 & -5.963 & -109.1 & -29.66 & 14.15 & 1.147 & 19.41 & 3.821 \\
\hline & $\mathrm{n}$ & 0.133 & 0.3523 & 0.05021 & 0.1578 & 0.2851 & 0.9024 & 0.3396 & 0.8583 \\
\hline \multirow{4}{*}{$\begin{array}{l}\text { Hue } \\
\text { angle }\end{array}$} & $K$ & -0.004811 & 0.001019 & -0.00799 & -0.02076 & 0.008712 & -0.00706 & 0.0000149 & 0.04231 \\
\hline & $C_{0}$ & 77.17 & 79.78 & 77.9 & 75.79 & 79.82 & 76.93 & 76.11 & 77.03 \\
\hline & $a$ & 0.1753 & -0.1347 & 0.2976 & 0.8045 & -1.151 & 0.2695 & -1.368 & -5.454 \\
\hline & $\mathrm{n}$ & 0.9879 & 1.342 & 0.12 & 0.7801 & 1.074 & 1.387 & 0.7311 & 0.9437 \\
\hline \multirow[t]{4}{*}{$B I$} & $K$ & 0.7646 & -0.09598 & -1.059 & -0.47 & 0.869 & 0.6983 & 0.8095 & -0.5099 \\
\hline & $C_{0}$ & 53.55 & 55.5 & 58.6 & 57.09 & 54.99 & 54.3 & 58.81 & 53.88 \\
\hline & $a$ & -72.28 & 4.953 & 23.91 & 18.35 & -85.95 & -58.27 & -76.45 & 28.76 \\
\hline & $\mathrm{n}$ & 0.1512 & 0.6383 & 0.4377 & 0.4549 & 0.1609 & 0.2585 & 0.2568 & 0.7702 \\
\hline
\end{tabular}


hue angle and browning index were made based on experimental data of infrared vacuum and microwave drying (Fig. 5-7).

The constant of kinetics rate based on the zero-order and first-order models under infrared vacuum conditions and microwave drying for the chroma and browning index increased and hue angle decreased with increasing air temperature and microwave power levels and decreasing absolute pressure. The zero-order model was better suited to describing the kinetics of chroma and browning index, while the first-order model was better to describe the kinetics of the hue angle.

The kinetic rate constants of $L^{*}, a^{*}, b^{*}$ and $\Delta E$ can be obtained by the new-model kinetics rate of chroma, hue angle and browning index at any moment using Eq. (12). The estimated kinetics parameters of the zero-order, first-order and new model for chroma, hue angle and browning index for various drying conditions were presented in Tables 3 to 5, respectively.

The zero-order and first-order kinetics models and new model were used to estimate the colour change kinetics of plum slices at any time during infrared vacuum conditions and microwave drying. Colour change of plum slices under infrared vacuum conditions was less compared to the microwave drying. Colour changes during the drying process of plum slices are of interest as these changes have a direct impact on consumers' decision to buy this product and can indicate retention of the pigment nutrients (e.g. carotenoids, flavonoids, phenols, chlorophyll and betalains) of dried plum slices.

\section{CONCLUSIONS}

The browning index of the dried plum slices showed that microwave drying caused browner compounds than infrared vacuum conditions. The zero-order and first-order kinetic models were used to explain the colour change kinetics and it was observed that $L^{*}$ and the hue angle fitted the first-order kinetic model. On the other hand, $a^{*}, b^{*}$, total colour change $(\Delta E)$, chroma and browning index followed the zero-order kinetic model. The results indicated that all kinetics changes of colour parameter can be explained with the new model presented in this study. The colour deterioration of dried plum slices at a higher air temperature, absolute pressure and microwave power level for maintaining product quality is necessary. The hybrid drying system included infrared vacuum conditions with microwave power for the initial slow drying of plum slices provide the desired results for colour change, which in turn are accepted by the consumer/producer.

\section{REFERENCES}

Ahmed, J., Kaur, A., Shivhare, U. (2002). Colour degradation kinetics of spinach, mustard leaves and mixed puree. J. Food Sci., 67 (3), 1088-1091.

AOAC (2002). Official methods of analysis. Arlington, USA: Association of Official Analytical Chemists.

Avila, I. M. L. B., Silva, C. L. M. (1999). Modelling kinetics of thermal degradation of colour of peach puree. J. Food Eng., 39(2), 161-166.

Barreiro, J. A., Milano, M., Sandoval, A. J. (1997). Kinetics of colour change of double concentrated tomato paste during thermal treatment. J. Food Eng., 33(3-4), 359-371.

Bozkurt, H., Bayram, M. (2006). Colour and textural attributes of sucuk during ripening. Meat Sci., 73(2), 344-350.

Chen, C. R., Ramaswamy, H. S. (2002). Colour and texture change kinetics in ripening bananas. LWT - Food Sci. Technol., 35(5), 415-419.

Dadalı, G., Apar, D. K., Ozbek, B. (2007a). Colour change kinetics of okra undergoing microwave drying. Drying Technol., 25(5), 925-936.

Dadalı, G., Demirhan, E., Ozbek, B. (2007b). Colour change kinetics of spinach undergoing microwave drying. Drying Technol., 25(10), 1713-1723.

FAO (2012). FaoStat: Agriculture Data. Retrieved from: http:/apps.fao.org/ page/collections? subset $1 / 4$ agriculture

Garza, S., Ibarz, A., Pagan, J., Giner, J. (1999). Non-enzymatic browning in peach puree during heating. Food Res. Int., 32(5), 335-343.

Goyal, R. K., Kingsly, A. R. P., Maniksntan, M. R., Ilyas, S. M. (2007). Mathematical modelling of thin layer drying kinetics of plum in a tunnel dryer. J. Food Eng., 79(1), 176-180.

Ibarz, A., Pagan, J., Garza, S. (1999). Kinetic models for colour changes in pear puree during heating at relatively high temperatures. J. Food Eng., 39(4), 415-422.

Kahyaoglu, T., Kaya, S. (2006). Modeling of moisture, colour and texture changes in sesame seeds during the conventional roasting. J. Food Eng., 75(2), 167-177.

Krokida, M. K., Maroulis, Z. B., Saravacos, G. D. (2001). The effect of the method of drying on the colour of 
dehydrated products. Int. J. Food Sci. Technol., 36(1), 53-59.

Maskan, M. (2001). Kinetics of colour change of kiwifruits during hot air and microwave drying. J. Food Eng., 48(2), 169-175.

Maskan, A., Kaya, S., Maskan, M. (2002). Effect of concentration and drying processes on colour change of grape juice and leather (pestil). J. Food Eng., 54(1), 75-80.

Milton, S. F. (1985). Some aspects of the chemistry of nonenzymatic browning (the Maillard reaction). In T. Richardson (Ed.), Chemical changes in food during processing (pp. 289-303). Westport, CT: AVI Publishing.

Palou, E., Lopez-Malo, A., Barbosa-Canovas, G., WeltiChanes, J., Swanson, B. G. (1999). Polyphenoloxidase activity and colour of blanched and high hydrostatic pressure treated banana puree. J. Food Sci., 64, 42-45.
Prachayawarakorn, S., Prachayawasin, P., Soponronnarit, S. (2004). Effective diffusivity and kinetics of urease inactivation and colour change during processing of soybeans with superheated-steam fluidized bed. Drying Technol., 22 (9), 2095-2118.

Sabarez, H. T., Price, W. E., Back, P. J., Woolf, L. A. (1997). Modelling the kinetics of d'Agen plums (Prunus domestica). Food Chem., 60(3), 371-382.

Sabarez, H. T., Price, W. E. (1999). A diffusion model for prune dehydration. J. Food Eng., 42(3), 167-172.

Yam, K. L., Papadakis, S. E. (2004). A simple digital imaging method for measuring and analyzing color of food surfaces. J. Food Eng., 61(1), 137-142. 